\title{
The changing balances of equity, control and market choice in the Indigenous vocational education and training sector
}

\author{
Don Zoellner \\ Northern Institute, \\ Charles Darwin University \\ don.zoellner@cdu.edu.au
}

\author{
Anne Stephens ${ }^{1}$ \\ The Cairns Institute, \\ James Cook University \\ anne.stephens@jcu.edu.au
}

Keywords: VET; Indigenous; public policy; markets

\begin{abstract}
The rationales and related programs for delivering vocational education and training to Indigenous Australians have seen significant change over the past 40 years, with several influential reviews marking policy pivot points along the way. Commencing with the 1960s Martin Review, the implementation by governments of selected recommendations have led to structural reforms and the creation of public policy instruments to monitor, regulate and control access to vocational training. These activities have heavily impacted Australian Indigenous people for whom certificate level qualifications are disproportionally the highest level of post-school education held. In the 'thin' markets of regional Australia, in particular, the authors of this paper argue that the changing priorities in training policy have systematically perpetuated inequity of access to, and benefit from vocational education and training, contrary to the original conception of a national post-secondary technical and further education system for Australia. Marketisation of the training sector and the transfer of funding responsibility from the public purse to the individual student/ worker have produced low rates of employment and high training attrition rates for Indigenous people. We argue that this arises from a fundamental shift in the meaning of equity itself which morphed from being considered a social good into an economic calculation.
\end{abstract}

\section{Introduction}

In Australian public policy deliberation there is an easy, uncritical acceptance of a particular social condition in regional and remote populations; one that depicts a complex, spiralling pathway of poverty, related social disadvantage and endless searches for solutions. The rhetoric links vocational education and training (VET) to economic and social development. Recent research (Ackehurst, Polvere, \& Windley, 2017 , p. 3) points to the continued appeal to Indigenous learners in remote areas that supports an earlier observation that the VET sector:

has an important role in addressing the diverse needs of Indigenous learners and thereby in making a significant impact on Indigenous educational disadvantage. Its strengths are based on its ability to accept adult students who have not completed secondary education into lower-level programs, and to offer a pathway through to higher level programs and qualifications, and, ultimately, into employment. (Helme, 2007, p. 454)

Through the years there have been significant increases in the participation of Indigenous people in the VET sector. According to Helme (2007, p. 453), there were approximately 3,300 students in the mid-1980s. In 1996 this number had grown to 10,900, and by 2013, was 32,900 (National Centre for Vocational Education Research, 2014, table 10). In a continuing demonstration that VET is regarded as the sector-of-choice for Indigenous people, by 2017 the number of students increased to 84,500 against the trend of an overall national decline of students enrolled in government-funded courses by nearly six per cent (National Centre for Vocational Education Research, 2018, p. 6). Part of VET's attraction is often 
attributed to its provision of a 'second chance' for those 'failed' by school education (Helme, 2007, p. 454) and the relative ease of access to VET in remote communities, particularly when compared to higher education (Ackehurst et al., 2017, p. 3).

VET is, however, criticised for being poorly coordinated, non-client-centric and not brokered in real placebased, developmental opportunities (Forrest, 2014, pp. 158-162). Against a post-colonial backdrop, training is implicated in the transmission of dominant cultural hegemony (Bourdieu, 1979, p. 142). Like the formal schooling sector for remote Indigenous children, when high VET enrolment rates and low course retention is coupled with high unemployment, VET is regarded as a costly problematic (Forrest, 2014 , p. 166). It is reported that two critical questions remain unanswered:

whether the current VET system is compatible with the values and aspirations of Indigenous communities; and how the system can adapt to provide training is culturally relevant to unique communities and their local employment opportunities. (Ackehurst et al., 2017, p. 13)

Public policy changes over the past 30 years have seen priorities shift from government delivery of VET to the marketisation of provision accompanied by funding changes to economic and social programs that have perpetuated inequity of access to, and benefit from, education. Current policy settings are quite contrary to the Kangan Review's (Australian Committee on Technical and Further Education, 1974) original conception of a post-secondary technical and further education system. This national inquiry's foundational premise was that social equity throughout Australia could be achieved by providing equitable access to training and further education. It was believed that by removing the barriers to entry each Australian resident would be able to acquire the appropriate skills and knowledge to enable participation in the workforce and thereby contribute to the growth of the country's economy.

Pivoting on the perception of choice, this was a project of self-improvement to be supplied through recurrent education and training provided by state-owned Technical and Further Education (TAFE) colleges. This was a non-market solution; government-funded and delivered education would bridge the gap between the skills available in the labour market and the needs of an increasingly globalised, high technology economy. The low achievement rates of Aboriginal Australians in the mid-1970s were to be addressed by the provision of better access to training (Australian Committee on Technical and Further Education, 1974, p. 17). Today, the policy environment is very different. There is a strong emphasis upon individual choice and participation chosen from a marketised training sector. However, for regional and remote Aboriginal and Torres Strait Islander Peoples the linkages between training, further study and employment are disjointed leading to low rates of employment and high training attrition rates (Ackehurst et al., 2017, p. 6; Guenther \& McRae-Williams, 2014).

The successive policy shifts that have taken place since the Kangan Review reveal a continual modification in the meaning of equity itself. Equity is an instrument for determining what counts as persuasive and rational knowledge. As a pivotal theme in the vocational training discourse, equity has often been used to justify the ascendency of particular policies that provide the architecture of the system. The changes in Australian public policy positions mirror larger contestations over the distribution and access to public goods and services. Government-funded post-secondary training progressively shifted from the Kanganera public monopoly over provision to a contestable market and a major transfer of funding responsibility from the public purse to the individual student/worker.

In 2017, 52.3 per cent of the 1.2 million government-funded students were in enrolled in TAFE and other government providers and 45.6 per cent were either enrolled with community education or other [private] registered providers (National Centre for Vocational Education Research, 2018, p. 5). Marketisation and privatisation have shifted the policy rationale for increasing the skills levels of the population from being framed as a pure public good in the name of national wellbeing to a private benefit that serves individual advancement (Productivity Commission, 2011, p. 58). In other words, there has been a rebalancing of the equation that links who benefits from and who pays for vocational education and training.

This paper is the result of a document review of reports and articles selected for their attention to equity and VET and their relevance to Indigenous Australians since the advent of the Technical and Further Education system in the mid-1970s through to the creation of training markets in which both public and 
private providers compete for government funding. We examine these shifts beginning with the Martin Review (Committee on the Future of Tertiary Education in Australia, 1964) and finish with the current Indigenous Advancement Strategy (IAS) (Department of Prime Minister and Cabinet, 2014). The authors draw upon Wolf's (1993) theory of non-market and market failure and trace the policy shifts where the meaning of equity was altered over the decades and what this has done to affect the perception of choice in terms of equitable access in a market for service provision and selection of training available in regional and remote Australia. Significant changes in national policies and their related programs can have a disproportionate impact on the Aboriginal and Torres Strait Islander Peoples who live outside of the major population centres due to cessation of support for training linked to self-determination and programs responding to locally determined priorities linked to culture, country and place. Indigenous residents report that programs are poorly targeted and divert significant resources into compliance reporting to funders and the frequent preparation of tenders to multiple, unrelated funding pools (Queensland Productivity Commission, 2018, p. 6). It is our central thesis that increased prevalence of conceptions of equity that are defined in economic terms (rather than social good) has facilitated changes in policies that have reduced/eliminated culturally appropriate local decision-making and ownership of the education/ employment nexus in favour of priorities and programs determined by central government agencies.

\section{Market theory and interpretation of equity}

Wolf (1993) provided a comparative analysis of the provision of goods and services through dualistically opposed market and non-market mechanisms. His definition of non-markets generally refers to government delivery but also includes the activities of not-for-profit organisations, philanthropic foundations, universities and religious organisations, but for clarity, we will use the term government and non-market interchangeably. Just as the theory of market failure serves as a useful corrective to the notion of perfectly functioning markets, Wolf (1993, pp. 12-13) asserts that his theories of non-market failure expose the limitations of the implicit concept of perfectly functioning governments. Both markets and non-markets demonstrate predictable and serious shortcomings. Having to choose market-based or government interventions 'may be simply a choice between the disagreeable and the intolerable' (Wolf, 1993, p. 90). The current vocational education and training public policy-making environment is not a binary choice between markets and governments, but rather a matter of altering the balance of different combinations of the two, frequently based on of multiple, competing priorities that include consideration of budget constraints, equity, employment, social welfare programs and levels of ideological purity.

In advocating for a more comprehensive theorisation of government failure, Wolf (1993, pp. 5-6) used public choice theory and its economic foundations of self-interest and rationality (Self, 1993, p. 4) to emphasise that 'the self-interest of politicians and bureaucrats is an important factor in understanding non-market processes'. He was concerned with human tendencies to ignore organisational inertia, tradition and standard operating routines, even though these contribute to government failures. Yet, the public's financial support for health and education is in part based upon arguments of market failure in privatised systems and that distributional equity is best provided by government for moral, social and ethical benefit (Adamson, Astrad, \& Darling-Hammond, 2016). It follows that some of the value of government provision of health and education will accrue to individuals in receipt of these services. Wolf (1993, p. 19) proposed that public policy decisions were mostly concerned with distributional issues, that is who gets the benefits and who pays, rather than efficiency issues, that is, how large are the benefits and costs.

The public provision of VET, particularly in regional and remote Australia, has been justified in the past on the basis of these distributional arguments and so-called thin markets. The Productivity Commission (2012, p. 57), has stated that 'there are a number of rationales for government intervention in the market for VET services, including to overcome market failures relating to the broader community benefits of education and information limitations about quality and benefits of education'. Government interventions have favoured particular constituents or targeted identifiable groups for improvement. The public provision of training in support of business and industry has been heavily promoted by lobbyists (for example, Lilly, 2016), legislators and political leaders (for example, Kemp, 1998) demonstrating the success of a longterm and consistent effort on the part of industry to minimise their own direct expenditure on vocational education and training (Business Council of Australia, 2017; Fraser, 1996). 
Likewise, advocates for so-called equity groups consistently argue the case for continued or increased government funding for education and training (Griffin, 2014; Griffiths, 1996; Lim, Gemici, Rice, \& Karmel, 2011; McIntyre, Volkoff, Egg, \& Solomon, 2004). Indigenous people are generally included in the equity groupings that have variously included youth, migrants, non-English speakers, women, the unemployed, remote residents and those with disability. With the introduction of mandatory reporting of national training data in the mid-1990s (Australian Committee on Vocational Education and Training Statistics, 1993) it became possible to monitor the government-funded VET participation and outcomes of these various groups at the population level. The commencement of Total VET Activity reporting by all training providers (National Centre for Vocational Education Research, 2015), allowed equity group VET study with private providers to be added to the knowledge base. Finally, the mandatory use of the Unique Student Identifier (USI) allows members of equity groups to be monitored at the individual level (VET National Data Strategy Action Group, 2010). The introduction of the rather Orwellian 'training entitlement' (Gillard, 2012) uses a combination of measures of disadvantage and the USI to control access to government subsidised VET. These surveillance methods also are in place to determine when any given individual reaches the upper limits of their entitlement so that they can be barred from the publicly-funded courses and sent into the self-funded private training market.

When a government-funded program is seen to fail, politicians are rewarded if they respond swiftly by 'publicising a problem and then instigating action as an ostensible remedy' (Wolf, 1993, p. 67). Wolf also laments that non-market activities may be authorised despite their 'infeasible objectives' and he warned that 'distributional inequality' is present in both market and government responses (p. 79). In the post-secondary training sector, there has been a renewed appetite to shift the balance towards an even greater degree of free-market orientation that transfers vast amounts of public funds into private profit through competitive bidding for government contracts and student loan schemes as part of this turn to the market (Yu \& Oliver, 2015). The VET FEE-HELP mechanism was used by some unscrupulous training providers to recruit regional and remote Indigenous students and saddle them with loan repayments for courses that were variably unsuitable, unlikely to be completed and/or of low quality (Bita, 2015). In responding to what can be described as a public policy disaster, the Australian Government Education Minister announced a replacement loan scheme to rectify the worst excesses of the original program (Saccaro \& Wright, 2018).

Equity, according to Wolf (1993, p. 93) has multiple definitions depending upon one's political, religious and paradigmatic view; he lists six definitions that have been used over the past 25 years to assist in developing and implementing policies based on the acceptance of different definitions of equity in ways that suit an evolving economic, marketised discourse:

- equality of opportunity (i.e., access)

- equality of outcome

- equality of a perfect outcome

- a categorical imperative to govern the behaviour of others as a general maxim

- horizontal equity (treating equally situated people equally)

- vertical equity (treating unequally situated people appropriately unequally)

Equity as defined by equality of access, outcome, variations on positive or negative discrimination and, as a mechanism of social control, can all be identified in the policy documents scrutinised here. The definition of equity used in the 1974 Kangan Report was a combination of equality of opportunity and vertical equity - treating unequally situated people appropriately unequally in order to improve accessibility to appropriate training for each individual. This was predicated on an ideology that supported access as a right of citizenship based on social justice imperatives and the desire to design the perfect outcome from the definitions above. Today, at least two of Wolf's definitions of equity can be found in the Indigenous Advancement Strategy. Vertical equity is observed in the stated intention to move towards equal outcomes in the area of employment by halving the gap between employment outcomes between Indigenous and other Australians by 2018 (Abbott, 2015, p. 2). A horizontal notion of equity justifies the strategy's allocation of public funds to training providers through the competitive grant application process in a quasi-market (Department of Prime Minister and Cabinet, 2014, p. 5). 


\section{Tracing equity: $\mathbf{4 0}$ years after Kangan}

Successive post-Menzies Australian Governments made increasing interventions into schooling and post-secondary education and training. The Martin Report of The Committee on the Future of Tertiary Education in Australia (1964) sought to address the lack of speciality technical colleges and proposed that higher education should be available to all citizens according to their needs and capacities. This report reflected Wolf's vertical equity view; one which treated unequally situated people appropriately unequally. The Martin Report saw education as a public investment yielding economic benefits through national skill-building. The result was a new system of colleges of advanced education, established by the Commonwealth Government. State governments were given responsibility for their management. According to Polesel and Teese (1998), this change of direction in policy and responsibility sharing between the Commonwealth and the States reflected both a need to increase the prestige of advanced technical education and a fiscal imperative to broaden the base of public revenue for industry training, although technical education remained the full funding responsibility of the states until 1975 (Klatt \& Polesel, 2013). The Australian Government 'assumed full responsibility for the funding of higher education from the states' in 1973 (Noonan, 2016, p. 3).

By 1974, under the Whitlam Government, it had become clear that the Australian workforce was lacking sufficient technical skills to meet the emerging needs of a rapidly changing and increasingly globalised economy. The TAFE in Australia: report on needs in Technical and Further Education (which became known as the Kangan Report) was commissioned to deal with 'the confusion of institutional eccentricity' of the chronically disparate and cash-strapped state training systems (Whitelock, 1974, p. 269). This landmark report is credited with the creation of an identifiable vocational training sector and policy framework of what had become known as TAFE - technical and further education (Goozee, 2001, p. 27). The Kangan Report drew heavily upon the work of bodies such as the International Labour Organisation and the Organisation for Economic Cooperation and Development (for example, see Faure et al., 1972) and recommended (Australian Committee on Technical and Further Education, 1974, p. xxiii) that the emerging national training system meet the needs of individuals by providing for:

the betterment and development of individual people and their contribution to the good of the community. Technical and further education should be planned accordingly. Emphasis on the needs of the individual should lead to easier access to learning, to better physical conditions for learning, to suitable student and teacher amenities, to welfare facilities, and to the highest standards for health and safety in workshops and laboratories.

The report placed an emphasis to the notion of recurrent education for post-school citizens. This meant that opportunities for technical and further education should be available to people of all ages regardless of previous education, location or employment status and give priority to the needs of the individual as a person. Development as a member of society, including non-vocational and social skills, was considered to be as important as the acquisition of technical learning. TAFE should create environments in which 'self-motivated individuals can reach their vocational goals and in which motivation may be regenerated in people who have lost it' (Australian Committee on Technical and Further Education, 1974, p. xvi). The Kangan Report was unambiguous: 'Universal access is a matter of equity' and should be seen as a 'fundamental right of the individual to prepare to earn a living within the social and industrial framework of society'; similarly no person should be deprived of an opportunity for post-school learning 'because of distance between his (sic) place of residence and an appropriate institution of learning'. (Australian Committee on Technical and Further Education, 1974, p. 85)

This became known as the Kangan philosophy (Hermann, 1982, p. 21) in which equity was equated with both of Wolf's vertical equity and equality of opportunity (access); the provision of education, training, specialist facilities and appropriately targeted support services was seen as a government-funded responsibility. 


\section{Aboriginal and Torres Strait Islander Peoples and VET}

The Kangan Report's definition of equity being in the form of every resident's education for personal and community benefit as well as human capital building prompted questions concerning the design of TAFE systems and the impact on the beneficiaries of the system. The review placed Aboriginal and Torres Strait Islander Peoples into a broad category of 'minority groups' and then treated these original Australians as an 'ethnic group' for purposes of policy and programs (Australian Committee on Technical and Further Education, 1974, p. 17). The TAFE system would be asked 'to make special efforts to ensure that ethnic groups are not denied access to TAFE because of communication problems' and that 10 per cent of a specific purpose recurrent funding grant be used 'to develop facilities to alleviate barriers to access discouraging ethnic groups' (Australian Committee on Technical and Further Education, 1974, pp. 86-87). This simplistic linkage of equity to access [of opportunity], eventually lost favour in mainstream Australia with the realisation that 'an approach based on principles of equity can perpetuate the very inequalities and injustices it is trying to overcome' (Teasdale \& Teasdale, 1996, pp. 16-17).

\section{An open market and private training providers}

The Kangan Report's authors did not envisage a market in which training providers would compete against each other and their conception of TAFE guided public vocational training policy until the early 1990s. Yet the seeds for a significant change in policy direction were planted in 1987 under the leadership of the Federal Education Minister, John Dawkins, who had amalgamated training into the Commonwealth Department of Education. This move represented a significant shift in the Australian political left, from the progressive or centre left, to the emerging influence of neoliberal economic rationalism (Morsy, Gulson, \& Clarke, 2014, p. 449). The education narrative was being rewritten. Education was now being cast as an instrumental tool for individual advancement in the service of economic development (Morsy et al., 2014 , p. 445). The rationale for public funding of VET as a public good associated with the building of citizenry was jettisoned in favour of a powerful new discourse of private benefit. This policy position has been uncritically adopted by all federal governments post-Dawkins (Zoellner, 2013, p. 145).

TheAustralian National Training Authority (ANTA) was established in 1992 and revolutionised the Australian VET system with competency-based standards of nationally recognised vocational qualifications in an industry-led system (Goozee, 2013, pp. 354-356). Its emergence was however a product of a significant dispute between the Commonwealth, state and territory governments over the responsibility for VET delivery and funding (Australian Senate Employment Education and Training References Committee, 1995). ANTA leveraged its concentration of policy-making and Commonwealth funding to produce a new national training system with an increasingly contestable training market of private and public providers which would be required to negotiate with industry for the provision of fee-for-service training; both could access public funding (Goozee, 2013, p. 410). The idea of a contestable training market had been introduced into the Australian policy rhetoric in the Deveson Report (Taylor, 1996). Deveson (1990, pp. 9-11) argued for the removal of TAFE's monopoly on the provision of government-funded qualifications on the premise that competition maximises responsiveness and hands responsibility for the choice of provider for students and employers.

The 1996 report, Pathways to where? Aboriginal and Torres Strait Islander participation in vocational education and training, anticipated that a 'far reaching policy shift - from equity to Indigenous rights' would have a major impact on the delivery of VET (Teasdale \& Teasdale, 1996, p. v). This report was highly critical of the statistical summaries used to measure Indigenous participation in VET. Such techniques, it claimed, reinforce disadvantage and structural racism that systematically restricted Indigenous access to educational opportunities (Helme, 2007, p. 452). Almost 20 years after the Kangan Review repeatedly noted the absence of vocational education data that would allow for the 'confident analyses of trends' (Australian Committee on Technical and Further Education, 1974, p. xviii) the Australian Vocational and Education Training Management Information System Standard (AVETMISS) had imposed a tightly prescribed, compulsory national reporting mechanism on all training organisations that issued formal qualifications and it has been progressively updated in order to inform political and ideological priorities of the day (National Centre for Vocational Education Research, 2010). Its collection of easily quantifiable indicators, (i.e., enrolments, completions, attendance, expenditure) informs interventions such as 
the Indigenous Advancement Strategy while excluding qualitative social indicators of discrimination, dispossession of land and cultural obligations. The aforementioned introduction of Total VET Activity reporting and the USI have only served to increase the scope of monitoring on a limited range of measures while continuing to ignore many of the issues that are important priorities for remote Indigenous residents (Ackehurst et al., 2017, p. 11). Some of these statistically invisible primacies include local language preservation, land rights, links to family, cultural obligations and customary economies (Altman, 2009, p. 9).

Pathways to Where? (Teasdale \& Teasdale, 1996, pp. v-vi) recommended the adoption of a rights-based interpretation of equity that would lead to a perfect outcome in Wolf's list; it stated that there ought to be:

increasing emphasis on Indigenous autonomy and self-determination in the management of VET programs... the control of VET for Indigenous Australians will increasingly be in their own hands. VET should become part of a more integrated and inclusive approach to community education that is open to all adults regardless of age or prior schooling. Aboriginal and Torres Strait Islander people should be encouraged to redefine the concept of VET. Teaching should incorporate Indigenous wisdom and learning and be more experientially based.

The report tangentially noted that opening up of the VET market also offered the potential for private training providers, including those controlled by Aboriginal and/or Torres Strait Islander Peoples interests, to access public funding: 'A number of localised providers also have responded to the expressed wishes of Indigenous people. The Institute for Aboriginal Development in Alice Springs and Tranby College in Sydney are two examples of institutions that are particularly valued by Indigenous people' (Teasdale \& Teasdale, 1996, p. 24). Indigenous controlled training organisations provide a real option for Indigenous students. However, the precarious nature of funding that result from the constantly changing policy environment and micro-management-type control of funding contracts limits the full potential of their reach into the training sector to better service the perceived needs of Indigenous Australians in a culturally appropriate manner (Zoellner, Stephens, Joseph, \& Monro, 2016).

The Teasdales' (1996, p. 24) report expressed the concern that an open training market which diminishes the public provider might limit the provision of lifelong learning opportunities for Indigenous people disproportionally:

Of all post-compulsory education providers, TAFE, the public vocational education and training provider, has the highest enrolments of Aboriginal and Torres Strait Islander people. Many TAFE's ability to establish programs in remote areas, as well as in rural and urban centres, is very advantageous to Aboriginal and Torres Strait Islander groups. By responding to the perceived needs of potential clientele in a particular context, TAFE has the opportunity to service Aboriginal and Torres Strait Islander students optimally. However, TAFE is the largest VET provider, and so has the highest enrolments. It is this extensive state and territory network across the nation, together with its ability to establish appropriate programs that gives TAFE the potential to provide even stronger and more relevant educational pathways for Indigenous Australians in the future.

Recommendations to engage VET as an instrument towards self-determination for Indigenous Australians ran headlong into the neoliberal rationale and its related new public management-style of policy implementation. Using contractual arrangements to control the activities of training providers, governments were able to justify withdrawing from direct service delivery and contracted away responsibility for the outcomes (Hill \& Hupe, 2002, pp. 110-112). In particular, the former secretary of the Australian Government's Department of Prime Minister and Cabinet agreed with Wolf that a market versus government power struggle is too simple; because the government uses managed markets 'to turn the apparently independent activities of free agents into instruments of government' (Keating, 2004, p. 4). Given that the ultimate goal of most public policy is to regulate or influence the behaviour of the population (Australian Public Service Commission, 2007, p. 1) through mechanisms described as 'government at a distance' (Miller \& Rose, 2008, p. 34), the aspiration for government-funded VET 
programs to be an instrument of Aboriginal and Torres Strait Islander Peoples' self-management was never likely to progress past the recommendation stage in the face of the national policy priority given to the marketisation of vocational education and training (Guthrie \& Clayton, 2018).

\title{
The political instrumentalisation of VET: a tool for national economic objectives
}

The first national strategy for the training sector by ANTA (1994), Towards a Skilled Australia, specified the state and territory roles in a restructured and competitive training market by developing detailed training profiles for each jurisdiction that prescribed course enrolments and delivery locations. The profiles allowed the Commonwealth to monitor the use of funding for both recurrent and infrastructure spending while the strategy centralised the choice of course offerings and sought to match training delivery to industry and skill national shortages in preference to locally determined priorities. In recognition of the costs associated with providing training in remote areas, the potential impact on choices of training available and to ameliorate the likelihood of market failure, the profile allowed for differential funding in so-called thin markets, i.e., greater support for TAFEs was provided on the basis of meeting 'community service obligations' (Fitzgerald, 1998, p. 20).

The 1990s and 2000s witnessed a rapid period of economic reform and further paradigmatic shifts. With changing global trends and the growth of supranational institutions, the VET system was under increasing pressure to address economy-wide problems. But the movement away from Kangan's public provision did not come without concerted and spirited attacks by commentators who decried the distancing of VET from its recurrent, lifelong learning roots laid out in the original report (Marginson, 1993, 1997). Billett (2010) warned of the social perils of abandoning the traditions of 'adult education' in favour of strictly defined utilitarian applications of technical education. Likewise, Wheelahan $(2008,2011)$ deplored the lack of theoretical knowledge contained in the Australian application of competency-based training and assessment accompanied by the continual downgrading of the professional teaching functions that had progressively taken place in the VET sector since the creation of ANTA. As the mainstream system shifted away from less tangible educational goals of the individual learner towards a system driven by competitive economic imperatives, what would be the impact felt on Indigenous Australians residing in country characterised as thin markets?

Partners in a learning culture: Australia's national Aboriginal and Torres Strait Islander strategy for vocational education and training 2000-2005 (Australian National Training Authority, 2000) was the next major report to alter the course of VET policy for the Indigenous training sector. The strategy was open to the 'development of a broader, more competitive training market' (p. 30), but acknowledged that Indigenous VET provision was still dominated by state government-funded TAFE providers. The policy also enabled one of the Dawkins-era seeds to flourish - the notion of obligation. The public good view of individual learning shifted to an onus on the individual to undertake training for employment. The strategy (p. 6) stated that:

\begin{abstract}
All Australians experience severe penalties if deprived of a learning culture and if excluded from life's opportunities, including work. Aboriginal and Torres Strait Islander people experience this loss more than most Australians as a result of historical discrimination, ongoing disadvantage and a rapidly changing contemporary Australia. Education and training specifically, and lifelong learning more generally, must be at the cutting edge of economic, social and cultural development for Aboriginal and Torres Strait Islander Australians in the new millennium.
\end{abstract}

In terms of equity, it was being redefined again into the desire to govern the behaviour of others (Wolf, 1993, p. 83). Politically, equity was now being used to instil a 'learning culture' in industry (Australian National Training Authority, 2000, p. 82) in what has become an exclusive welding of VET to economic outcomes. This linkage serves to erode the real choices of occupational training for Indigenous people residing in regional and remote regions (Ackehurst et al., 2017, p. 11) by using the VET sector for the purposes of fulfilling mutual obligations to society at large (Quiggin, 2013, p. 60).

ANTA's (2000, p. 7) vision for VET for Indigenous Australians was to renew and share: 
an Indigenous learning culture with all Australians in a spirit of reconciliation, equity, justice and community economic development and sustainability. This vision can be shared by all Australians who support the aspirations of Indigenous people in Australia. This vision is for:

- $\quad$ cultural affirmation and community choice, enabled by

- $\quad$ equal opportunity and affirmative action, leading to

- $\quad$ flexible delivery, equitable outcomes and lifelong learning, resulting in

- $\quad$ community economic development and sustainability contributing to

- $\quad$ reconciliation and justice in Australia.

The strategy aims to achieve this vision, through a partnership between Indigenous Australian communities, governments, industry and training/education providers. We are all equal partners in building a learning culture.

In effect, ANTA's national strategy re-inserted the active social policy of lifelong learning, but within the limited utilitarian goal of leading to employment. The introduction of an Indigenous learning culture recast equity in terms of validity and fairness, which was conditional on economic consideration that tied traditional culture to modern employment and training markets. This was seen as the solution to a range of social inequalities experienced by the Indigenous population that had become reduced to seven easily quantifiable 'closing the gap' targets that generally relied upon existing statistical gathering mechanisms such as the AVETMISS (Abbott, 2015, p. 5). This move ended the previous decade's commitment to self-determination and styles of program development that recognised both culture and place. ANTA was unilaterally abolished in 2004 (Noonan, 2016, p. 7). The Howard Coalition Government, in order to exert greater levels of ministerial control over the VET sector post-ANTA, did not instigate another national VET strategy for Aboriginal and Torres Strait Islander Peoples.

Vocational training for Indigenous learners was subsumed into the Rudd Government's whole-ofgovernment Closing the Gap agenda in 2007 (for example, see Carapetis, 2010) and specific programs were operationalised through National Partnership Agreements (NPAs) between the state, territory and federal governments (Council of Australian Governments, 2009). NPAs stipulated the quantum and scope of Commonwealth funding dedicated to vocational training (see Council of Australian Governments, 2008, 2012). Agreements contained specific references to targets of the same mechanistic and reductionist nature that had been criticised by Teasdale \& Teasdale (1996) and others (for example, Altman, 2009). NPAs were intended to resolve the problematic and quantified sets of disparities, or gaps, between the general population and Indigenous people. Reducing these gaps through the provision of carefully targeted programs - a type of vertical equity that treats unequally situated people differently - was in use as was an ever-increasing contracting out of government programs to private providers (National Centre for Vocational Education Research, 2016).

\section{From the Productivity Commission to the Indigenous Advancement Strategy: the era of individualisation}

The Productivity Commission's (2012, p. 39) investigation into government funding and regualtion of the VET sector found that the benefits from training particpation are both 'private' and 'public'. The private advantages, in alignment with Becker's (1993, p. 17) human capital theory, are measured in terms of higher remuneration or other job-related benefits directly aligned with increased levels of education and training. The public gains associated with education, are less tangible but include innovation, better health, social cohesion, support for a functioning democracy and reduced criminal activity (Productivity Commission, 2012, p. 59). The civic benefits of education and training are typically attributed to participation in primary and secondary education yet VET has the capacity to 'remedy the foundation skill deficits of some learners might also generate significant benefits of this type' (Productivity Commission, 2012, p. 60). In distant echoes of the Kangan philosophy, the Productivity Commission also noted that governments typically consider access to VET inequitable in a free market. Unlike Kangan, however, the Productivity Commission (2012, p. 19) unequivocally supported further marketisation of VET:

The Commission anticipates that, over time, there would be a gain in moving from a 
regulated and supply driven system to a demand driven contestable market, provided quality is maintained. In fact, with improved information to prospective students and employers, and stronger auditing and validation of course outcomes, improved quality should result over time. And there could be cost savings at constant quality. For illustrative purposes, assuming a 2 per cent improvement in the efficiency of delivering services in the publiclyfunded VET sector (estimated to be about $\$ 7.5$ billion in size); this would be equivalent to about $\$ 150$ million in 2010 dollars. A more efficient and flexible VET sector would be expected to also improve the functioning of the labour market (through faster retraining and better matching of people to vacancies).

The former Prime Minister Abbott's revised approach to the Close the Gap policy collapsed 150 separate programs from across a range of government agencies into five thematic categories and explicitly linked program funding to the broad policy intention of 'getting Indigenous Australians into work' (Department of Prime Minister and Cabinet, 2014, p. 3). One result is that Indigenous vocational training policy came under the auspices of the IAS (Guenther, 2017). This Indigenous Advancement Strategy placed full faith in the ability of market-driven approaches to achieve the desired outcomes with the bulk of grant funding allocated through 'open competitive grant rounds' (Department of Prime Minister and Cabinet, 2014, p. 5). By Wolf's (1993) standards, the IAS is an example of non-market activity, regardless of the Australian Government's attempts to extract greater efficiency from Indigenous programs using competition between providers. The types of activities to be funded and the outcomes desired were centrally determined by government. At best, the IAS has created a highly regulated quasi-market for the allocation of public funds through strictly enforced legal contractual obligations that are driven by 'the capacity of governments to manage markets in pursuit of their ongoing policy ideals' (Keating, 2004, p. 175).

The IAS is not a policy promoting self-determination, neither does it comment on the community and cultural benefits of Indigenous vocational education and training expressed in the Kangan philosophy. The outcomes of the IAS were those 'identified as the priorities of government, not the intended beneficiaries of programs' (Altman, 2014, p. 109), particularly for people living in remote areas who are subject to quite specific targets described in the IAS. The long-standing preference for recurrent or lifelong learning, as a project of continuous personal improvement, is removed from consideration. Instead the focus of funding is on the immediate and short term; specified as 'activities that support employment outcomes for Indigenous jobseekers, including retention at 26 weeks' (Department of Prime Minister and Cabinet, 2014 , p. 11). The ongoing obligation to undertake a project of self-improvement by constantly retraining has been replaced by a minimal requirement to stay in any of sort paid employment for six months.

The IAS is a bi-partisan social policy that attempts to increase market-like responses to the overwhelming disparity experienced by Aboriginal and Torres Strait Islander Peoples. The centrally pre-determined goals include, and are not limited to, increased private home ownership on Indigenous land, agreements to improve school attendance, employment and safer communities (Department of Prime Minister and Cabinet, 2014, p. 17). Yet the reality for those Indigenous Australians residing in the thin markets of remote Australia is that open market choices have always been limited. The opportunities to select from a well-priced range of services they feel to be appropriate to their circumstances are fewer than urban areas. But the ideal for choice is now absent from the IAS. The IAS compounds the present lack of choice people have by failing to respond to individual or even local community priorities in favour of centralised control of residents' behaviour through the use of contractors. Furthermore, the concept of equity for Indigenous people disappeared entirely from the strategy. The only reference to equity relates to how the Department of Prime Minister and Cabinet will treat applicants for grant funding in open competitive bidding (Department of Prime Minister and Cabinet, 2014, p. 5). From Wolf's perspective, the definition of equity implicit in the IAS treats unequally situated people unequally.

The Competition Policy Review: Final Report (Harper, Anderson, McCluskey, \& O’Bryan, 2015) was the most recent piece of public policy calling for the marketisaton of previously non-economic sectors to be commissioned by the Abbott/Turnbull Governments. It was the first major national examination of the role of competition in the Australian economy since the Hilmer Report in 1993. Where Hilmer had ignored competition in the provision of human services, the Harper Report recommended that markets be designed for the delivery of human services because they will provide 'greater diversity, choice and 
responsiveness in government services [and] can both empower consumers and improve productivity' (Harper et al., 2015, p. 24). These future markets should be developed based on a 'presumption of choice' by citizens and in yet another ironic twist, resource allocations should take into account equity of access, universal service provision and minimum quality (Harper et al., 2015). The advocates for these new public management styles of service provision do not allow for even the possibility that markets may not provide the best solution for the delivery of public services; past failures (such as in VET FEEHELP) are attributed to 'inadequacies in the contract specification rather than fundamental flaws in any contractual model for service delivery' (Keating, 2004, p. 95).

\section{Conclusion}

Wolf (1993, p. 160) maintained that government solutions display just as many problems as do markets. The current default policy preference for delivering public services by open competitive tendering produces a situation where it appears that the worst of both markets and non-markets exacerbate pre-existing sets of inequities. Governments, by definition, can only bring their forces to bear to redistribute capital and resources to redress the inequities of opportunity and outcome that accumulate when markets are given free reign. However, the restorative capacity of the IAS interventions is arguable, and no matter how well intentioned, the remedy may be as bad, or even worse, than the original complaint.

In our view, the culmination of progressive policy shifts to the marketisation of the VET and the creation of the IAS have erased the presumption of individual choice for Indigenous people in favour of central government preferences. Indigenous residents of remote communities still do not experience high completion rates of formal qualifications or the related improvements in employment outcomes (Ackehurst et al., 2017, p. 1). The endurance of market-based solutions, predicated upon an unquestionable linkage between social outcomes and the economic imperative of paid employment, has easily migrated to the centre of resource allocation decisions since the seed was planted by Dawkins. The result has altered the fundamental objective of education from a communitarian project of individual self-improvement to private personal benefit. Paradoxically, the design and conduct of the IAS moves in exactly the opposite direction. With the categorisation of Aboriginal and Torres Strait Islander Peoples as a 'Priority Population Group' (Department of Education and Training, 2015) and outsourced contractors bidding for Commonwealth funds in response to ministerially determined criteria and reporting requirements, this is not a place where individuals exercise the discipline of the market. The advocates for market-based approaches run head-long into those who see value in the ability of governments to give effect to political and philosophical ambitions. This clash has served to even further marginalise Indigenous peoples' longheld desire for place-based solutions to social and economic problems facing their communities.

While choice, which plays out at the core of markets, has always been more limited in rural and remote settings, the ideal of choice was not entirely absent from the policy settings prior to or since ANTA. Yet the continued reforms of the VET sector over 40 years and the erasure of the local/individual choice of training by provider and/or course content, has culminated in today's confused policy mix. There is a grave risk that this version of equity and the quasi-market-based solution of the IAS will widen the gaps that have been identified for closing.

What does this situation say about the demand for VET training by Indigenous people in remote and regional communities across Australia? Do they exercise the same discretionary choices concerning access to quality training provision as people residing in more heavily populated urban and city centres? Australian public policy is confused because high level statement of intent often suggest support for training services to be available as envisaged in the Kangan philosophy of the 1970s. For example, lifelong learning is still recognised as 'a more important means of securing rewarding employment' (Harper et al., 2015 , p. 24), yet the introduction of training entitlements places a life-time cap on the amount of publicly supported training any individual can receive. In thin competitive markets, unscrupulous training providers can sign people up to low quality courses in order to extract the maximum profit while exhausting and individual's entitlement. Equity defined as access and a need for continual retraining, is also about the choices people have on where to do training - not necessarily through a host of providers, but a stable, non-market institutional setting that can efficiently identify and respond locally to needs, workforce gaps and changing tastes and interests of individuals seeking rewarding employment opportunities. 
The shifting balance between equity, control and marketisation of the sector has also been about resolving the tension between who benefits and who pays for training. This long-standing conflict between the various jurisdictions and the VET system's institutions has clearly had an impact on the Indigenous people living in the remote areas. The determination of successive policies to develop functional competitive markets across the sector has come at a cost not only to the primary motivation for participation in terms of recurrent education but has reduced the value of training that is recognised as having tangible educational goals that produce both positive individual and the social outcomes. When cost transference to the individual from the responsibility of government to deliver, real choice, equity of access, relevance and community determination has been effectively erased, the question remains, for how much longer can training be the solution? 


\section{References}

Abbott, T. (2015). Closing the gap: Prime Minister's report 2015. Retrieved from Canberra: https://www. dpmc.gov.au/sites/default/files/publications/Closing_the_Gap_2015_Report.pdf

Ackehurst, M., Polvere, R. A., \& Windley, G. (2017). Indigenous participation in VET: understanding the research. Retrieved from Adelaide: https://www.ncver.edu.au/research-and-statistics/ publications/all-publications/indigenous-participation-in-vet-understanding-the-research

Adamson, F., Astrad, B., \& Darling-Hammond, L. (Eds.). (2016). Global education reform: how privatisation and public investment influence education outcomes. New York: Routledge.

Altman, J. (2009). Beyond Closing the Gap: valuing diversity in Indigenous Australia. Retrieved from Canberra: http://caepr.cass.anu.edu.au/research/publications/ beyond-closing-gap-valuing-diversity-indigenous-australia

Altman, J. (2014). Commentary on the consequences: Abbott's back to the future policy for Aborignal advancement. Journal of Indigenous Policy(16), 108-112.

Australian Committee on Technical and Further Education. (1974). TAFE in Australia: report on needs in Technical and Further Education (Kangan Report) Retrieved from Canberra: http://www.voced. edu.au/content/ngv38436

Australian Committee on Vocational Education and Training Statistics. (1993). Australian Vocational Education and Training Management Information System Standard: Volume One: An Overview: Release 1.0. Retrieved from Perth: http://hdl.voced.edu.au/10707/124081

Australian National Training Authority. (1994). Towards a skilled Australia: a national strategy for vocational education and training. Retrieved from Brisbane: http://hdl.voced.edu.au/10707/29930

Australian National Training Authority. (2000). Partners in a learning culture: Australia's national Aboriginal and Torres Strait Islander strategy for vocational education and training 2000 until 2005. Retrieved from Brisbane: http://hdl.voced.edu.au/10707/47059

Australian Public Service Commission. (2007). Changing behaviour: a public policy perspective. Canberra: The Australian Government.

Australian Senate Employment Education and Training References Committee. (1995). Report of the inquiry into the Australian National Training Authority. Retrieved from Canberra: http://www.voced. edu.au/content/ngv39231

Becker, G. (1993). Human capital: a theoretical and empirical analysis with special reference to education (Third ed.). Chicago: The University of Chicago Press.

Billett, S. (2010). The perils of confusing lifelong learning with lifelong education. International Journal of Lifelong Education, 29(4), 401-413.

Bita, N. (2015, 25 March 2015). Trainers target indigenous marks: ACCC. The Australian, p. 5.

Bourdieu, P. (1979). Distinction: a social critique of the judgement of taste. London: Routledge and Kegan Paul.

Business Council of Australia. (2017). Future-proof: protecting Australians through education and skills. Retrieved from Melbourne: http://www.bca.com.au/publications/ future-proof-protecting-australians-through-education-and-skills

Carapetis, J. (2010). Evidence to close the gap. Australian Medicine, 22(5), 26.

Committee on the Future of Tertiary Education in Australia. (1964). Tertiary education in Australia [Martin report]. Retrieved from Melbourne: http://hdl.voced.edu.au/10707/228215 
Council of Australian Governments. (2008). National agreement for skills and workforce development. Retrieved from Canberra: http://www.federalfinancialrelations.gov.au/content/national_ agreements.aspx

Council of Australian Governments. (2009). National Indigenous Reform Agreement (Closing the Gap). Canberra: Australian Government.

Council of Australian Governments. (2012). National partnership agreement on skills reform. Retrieved from Canberra: https://docs.education.gov.au/system/files/doc/other/skills-reform_np.pdf

Department of Education and Training. (2015). For training providers: funding and pricing. Retrieved from http://www.training.qld.gov.au/training-organisations/funded-programs/user-choice/fundedpricing/index.html

Department of Prime Minister and Cabinet. (2014). Indigenous advancement strategy guidelines. Retrieved from http://www.dpmc.gov.au/sites/default/files/publications/ias_guidelines.pdf

Deveson, I. (1990). Training costs of award restructuring: report of the Training Costs Review Committee: volume one. Retrieved from Canberra: http://www.voced.edu.au/content/ngv35846

Faure, E., Herrera, F., Kaddoura, A. R., Lopes, H., Petrovsky, A., Rahnema, M., \& Ward, F. (1972). Learning to be: the world of education today and tomorrow. Retrieved from Paris: http://unesdoc. unesco.org/images/0000/000018/001801e.pdf

Fitzgerald, V. (1998). Market frameworks in VET. In C. Robinson \& R. Kenyon (Eds.), The market for vocational education and training. Adelaide: National Centre for Vocational Education Research.

Forrest, A. (2014). The Forrest review: creating parity. Retrieved from Canberra: http://api.ning.com/files/ zR-FkEEcSb-QhddJtkCMtG5-wESBtnJ9EqjRmzC7vbfEv7KNU2m4c1NiomE3mvZc0vDpbimgBnr T1c54V1OOui8QNZRxKuKD/ForrestReviewCreatingParity.pdf

Fraser, D. (1996). Training guarantee: its impact and legacy 1990-1994: main report. Retrieved from Canberra: http://www.voced.edu.au/content/ngv\%3A18958

Gillard, J. (2012). Speech to launch "Skills for All Australians". Retrieved from http://www.pm.gov.au/ press-office/speech-launch-skills-all-australians-canberra

Goozee, G. (2001). The development of TAFE in Australia (Third ed.). Leabrook: National Centre for Vocational Education Research.

Goozee, G. (2013). From Tech to TAFE: 1949-1997. Sydney: Retired New South Wales TAFE Officers' Association.

Griffin, T. (2014). Disadvantaged learners and VET to higher education transitions. Retrieved from Adelaide: http://hdl.voced.edu.au/10707/318642

Griffiths, D. (1996). Development of a spatial model to quantify access to services in rural and remote areas of Australia. (Doctor of Philosophy), Northern Territory University, Darwin. Retrieved from http://trove.nla.gov.au/work/153152676?q\&versionld=166908407

Guenther, J. (2017). Policy snapshot: Indigenous training and employment. Adelaide: National Centre for Vocational Education Research.

Guenther, J., \& McRae-Williams, E. (2014). Does education and training for remote Aboriginal and Torres Strait Islanders lead to 'real' jobs? Evidence from the 2011 Census. Paper presented at the 17th AVETRA International Conference: Informing changes in VET policy and practice: The central role of research, Surfers Paradise. http://eprints.batchelor.edu.au/402/ 
Guthrie, H., \& Clayton, B. (2018). VET policy: processes, stakeholders and issues. Retrieved from Melbourne: https://melbourne-cshe.unimelb.edu.au/lh-martin-institute/news/vocationaleducation-for-the-21st-century-a-series-of-policy-discussion-papers/vocational-education-forthe-21st-century-a-series-of-policy-discussion-papers?utm_source=TDA+Newsletter\&utm _ campaign=5dd9d4e859-EMAIL_CAMPAIGN_2018_08_05_10_19\&utm_medium=email\&utm_ term=0_5e410b5720-5dd9d4e859-504280097

Harper, I., Anderson, P., McCluskey, S., \& O’Bryan, M. (2015). Competition policy review: final report. Retrieved from Canberra: http://competitionpolicyreview.gov.au/final-report/

Helme, S. (2007). From the sidelines to the centre: Indigenous support units in vocational education and training. Journal of Vocational education and Training, 59(4), 451-466. doi:10.1080/13636820701650901

Hermann, G. (1982). Research in TAFE in the 1980s: a listing of some Kangan Report recommendations in order to provide a context for the discussion of research items in TAFE. Retrieved from Adelaide: http://hdl.voced.edu.au/10707/42200

Hill, M., \& Hupe, P. (2002). Implementing public policy: governance in theory and practice. London: Sage Publications.

Keating, M. (2004). Who rules?: How government retains control of a privatised economy. Sydney: The Federation Press.

Kemp, D. (1998). The VET market. In C. Robinson \& R. Kenyon (Eds.), The market for vocational education and training. Leabrook: National Centre for Vocational Education Research.

Klatt, M., \& Polesel, J. (2013). Vocational education and training in Australia and three-dimensional federalism. Australian Journal of Education, 57(1), 74-86.

Lilly, M. (2016). The future of Australian apprenticeships: what is required for Australia to strengthen its value and commitment to a quality apprenticeship system? Melbourne: The Australian Industry Group.

Lim, P., Gemici, S., Rice, J., \& Karmel, T. (2011). Socioeconomic status and the allocation of government resources in Australia: how well do geographic measures perform? Education + Training, 53(7), 570-586.

Marginson, S. (1993). Education and public policy in Australia. Cambridge: Cambridge University Press.

Marginson, S. (1997). Markets in education. St Leonards: Allen and Unwin.

Mclntyre, J., Volkoff, V., Egg, M., \& Solomon, N. (2004). Understanding equity strategies of training providers. Retrieved from Adelaide: http://hdl.voced.edu.au/10707/93508

Miller, P., \& Rose, N. (2008). Governing the present: administering economic social and personal life. Cambridge: Polity Press.

Morsy, L., Gulson, K., \& Clarke, M. (2014). Democracy, 'sectorblindness' and the delegitimation of dissent in neoliberal education policy: a response to Discourse 34(2), May 2013. Discourse: studies in the cultural politics of education, 35(3), 444-461.

National Centre for Vocational Education Research. (2010). Australian Vocational Education and Training Management Information Statistical Standard data element definitions (Second ed.). Adelaide: National Centre for Vocational Education Research.

National Centre for Vocational Education Research. (2014). Historical time series for vocational education and training in Australia from 1981. Retrieved from Adelaide: http://www.voced.edu.au/ content/ngv\%3A63619 
National Centre for Vocational Education Research. (2015). Total VET students and courses 2014. Retrieved from Adelaide: http://hdl.voced.edu.au/10707/384117

National Centre for Vocational Education Research. (2016). Vocational education and training statistics: total VET students and courses 2015. Retrieved from Adelaide: https://www.ncver.edu.au/ publications/publications/all-publications/2874

National Centre for Vocational Education Research. (2018). Australian vocational education and training statistics: government-funded students and courses 2017. Retrieved from Adelaide: https://www.ncver.edu.au/publications/publications/all-publications/ government-funded-students-and-courses-2017

Noonan, P. (2016). VET funding in Australia: background, trends and future directions. Retrieved from Melbourne: http://www.mitchellinstitute.org.au/reports/ vet-funding-in-australia-background-trends-and-future-options/

Polesel, J., \& Teese, R. (1998). The colleges: growth and diversity in the non-university tertiary studies sector (1965-1974). Canberra: Department of Employment, Education, Training and Youth Affairs.

Productivity Commission. (2011). Vocational education and training workforce: Productivity Commission research report. Retrieved from Canberra: http://www.pc.gov.au/inquiries/completed/educationworkforce-vocational/report/vocational-workforce.pdf

Productivity Commission. (2012). Impacts of COAG reforms: business regulation and VET, research report, volume 3 - VET. Retrieved from Canberra: http://www.pc.gov.au/inquiries/completed/ coag-reporting-busines-vet/report/coag-reform-vet.pdf

Queensland Productivity Commission. (2018). Lessons from the inquiry into service delivery to Indigenous communities. Brisbane: Queensland Productivity Commission.

Quiggin, J. (2013). Education as an industry, and as a product. In F. Beddie, L. O'Connor, \& P. Curtin (Eds.), Structures in tertiary education and training: a kaleidoscope or merely fragments? research readings (pp. 60-68). Adelaide: National Centre for Vocational Education Research.

Saccaro, F., \& Wright, R. (2018). VET FEE-HELP: what went wrong? Retrieved from Melbourne: https:// melbourne-cshe.unimelb.edu.au/lh-martin-institute/news/vocational-education-for-the-21stcentury-a-series-of-policy-discussion-papers/vocational-education-for-the-21st-century-aseries-of-policy-discussion-papers?utm_source=TDA+Newsletter\&utm_campaign=5dd9d4e859EMAIL_CAMPAIGN_2018_08_05_10_19\&utm_medium=email\&utm_term=0_5e410b57205dd9d4e859-504280097

Self, P. (1993). Government by the market? The politics of public choice. Basingstoke: The MacMillan Press Limited.

Taylor, R. (1996). Report of the review of the Australian National Training Authority Agreement. Retrieved from Canberra: http://www.voced.edu.au/content/ngv36118

Teasdale, J., \& Teasdale, R. (1996). Pathways to where?: Aboriginal and Torres Strait Islander participation in vocational education and training. Retrieved from Adelaide: http://hdl.voced.edu. au/10707/104592

VET National Data Strategy Action Group. (2010). A unique student identifier for Australia's vocational education and training system. Retrieved from Adelaide: http://hdl.voced.edu.au/10707/509

Wheelahan, L. (2008). Can learning outcomes be divorced from processes of learning? Or why training packages make very bad curriculum. Retrieved from https://www.avetra.org.au/data/Conference Archive_2008/9._Leesa_Wheelahan.pdf

Wheelahan, L. (2011, 18 May 2011). Report downgrades VET teachers. The Australian, p. 30.

Whitelock, D. (1974). The great tradition: a history of adult education in Australia. St Lucia: University of Queensland Press. 
Wolf, C. (1993). Markets or governments: choosing between imperfect alternatives (Second ed.). Cambridge: MIT Press.

Yu, S., \& Oliver, D. (2015). The capture of public wealth by the for-profit VET sector: a report prepared for the Australian Education Union. Retrieved from Sydney: http://www.aeufederal.org.au/application/ files/9614/3315/0486/WRCAEU2015.pdf

Zoellner, D. (2013). If vocational education and training is the answer, what was the question?: theorising public policy and the behaviour of citizens. (Doctor of Philosophy), Charles Darwin University, Darwin. Retrieved from http://hdl.voced.edu.au/10707/289868

Zoellner, D., Stephens, A., Joseph, V., \& Monro, D. (2016). Mission-driven adaptability in a changing national training system. The Australian Journal of Indigenous Education, 1-10. Retrieved from doi:10.1017/jie.2016.24 